\title{
AKTIVITAS ANTIBAKTERI SALEP DENGAN BAHAN AKTIF EKSTRAK KUNYIT, KENCUR DAN TEMUGIRING TERHADAP BAKTERI STAPHYLOCOCCUS AUREUS
}

\author{
Bambang Yunianto, Titik Lestari, Agus Winarso \\ Kementerian Kesehatan Politeknik Kesehatan Surakarta Jurusan Jamu
}

\begin{abstract}
Antibacterial Activity, Skin ointment, Turmeric, Kaemferia galanga L, Curcuma heyneana. Indonesia is a country with a very high biodiversity. In the high diversity are stored potent plant potentials that can be extracted and utilized further. People are starting to realize the use of chemicals to solve life problems, especially health problems, in addition to expensive, can also cause adverse side effects for humans. Human life is always surrounded by microbes, either pathogenic or nonpathogenic. Many plants that have properties as antibacterial, such as turmeric, Kaemferia galanga L. and Curcuma heyneana. This research use turmeric, Kaemferia galanga L. And Curcuma heyneana extract, as active ingredient of skin ointment. This study aimed to know the extent to which the antibacterial activity of these three ointments against Staphylococcus aureus bacteria. This type of research was quasi experimental, with the design of Static Group Comparasion. Activity test with wells method with diameter $6,5 \mathrm{~mm}$ showed that the mean of clear zone were Kaemferia galanga L. (14,52 mm), turmeric $(13,26 \mathrm{~mm})$, Curcuma heyneana $(7,89 \mathrm{~mm})$, and control $(6.49 \mathrm{~mm})$
\end{abstract}

Keywords : Antibacterial Activity, Skin ointment, Turmeric, Kaemferia galanga L, Curcuma heyneana

Abstrak: Aktivitas antibakteri, Salep, Kunyit, Kencur, Temugiring. Indonesia merupakan negara dengan keanekaragaman hayati yang sangat tinggi. Dalam keanekaragaman yang tinggi tersebut tersimpan potensi tumbuhan berkhasiat yang dapat digali dan dimanfaatkan lebih lanjut. Masyarakat mulai sadar penggunaan bahan kimia untuk mengatasi masalah kehidupan, terutama masalah kesehatan, selain biayanya mahal, juga dapat mengakibatkan efek samping kurang baik bagi manusia. Kehidupan manusia selalu dikelilingi oleh mikroba, baik yang patogen maupun tidak patogen. Banyak tumbuhan yang mempunyai khasiat sebagai antibakteri, diantaranya adalah kunyit, kencur dan temugiring. Penelitian ini akan menggunakan ekstrak kunyit, kencur, dan temugiring sebagai bahan aktif salep kulit. Penelitian ini bermaksud mengetahui sejauh mana aktivitas antibakteri ketiga salep tersebut terhadap bakteri Staphylococcus aureus. Jenis penelitian ini adalah eksperimental semu, dengan rancangan Static Group Comparasion. Uji aktivitas dengan metode sumuran dengan diameter $6,5 \mathrm{~mm}$ menunjukkan hasil bahwa rata-rata zona bening berturut-turut adalah : kencur $(14,52 \mathrm{~mm})$, kunyit $(13,26 \mathrm{~mm})$, temugiring $(7,89 \mathrm{~mm})$, dan kontrol $(6,49 \mathrm{~mm})$

Kata Kunci: Aktivitas antibakteri, Salep, Kunyit, Kencur, Temugiring 


\section{PENDAHULUAN}

Indonesia merupakan salah satu negara tropis, memiliki keanekaragaman hayati yang tinggi, kaya akan flora dan fauna. Sebagian besar tumbuhan tersebut dapat digunakan sebagai tumbuhan berkhasiat obat. Tumbuhan berkhasiat obat yaitu tumbuhan atau bagian dari tumbuhan yang berupa daun, batang, buah, bunga dan akarnya yang memiliki khasiat sebagai obat, dan digunakan sebagai bahan mentah dalam pembuatan obat modern maupun obat-obatan tradisional, salah satunya adalah salep (Peoloengan, 2006). Salep dengan bahan aktif dari tumbuhan obat diharapkan mampu menangani masalah infeksi, khususnya di daerah permukaan kulit, salah satunya disebabkan oleh bakteri Staphylococcus aureus.

Penelitian mengenai tumbuhan obat yang memiliki aktivitas antibakteri telah dilakukan sebelumnya baik secara sendiri-sendiri tiap jenis tumbuhan, maupun secara kombinasi dari beberapa jenis tumbuhan yang mempunyai aktivitas antibakteri, diantaranya adalah tumbuhan temu-temuan dari suku Zingiberaceae. Tumbuhan obat tersebut diantaranya adalah kunyit (Curcuma domestica), kencur (Kaempferia galanga L.) dan temugiring (Curcuma heyneana Val. \& v. Zijp). Kunyit mengandung senyawa aktif yaitu kurkumin dan minyak atsiri, mempunyai peranan sebagai antioksidan, antitumor, antikanker, antipikun, antiracun dan antimikroba. Penelitian sebelumnya baik secara in-vitro, in-vivo dan uji klinis membuktikan bahwa kunyit bersifat antimikroba yang dapat menghambat pertumbuhan dan membunuh beberapa jenis jamur, bakteri dan virus (Anonim, 2013).
Tumbuhan kencur mengandung minyak atsiri. Zat-zat yang banyak diteliti adalah pada rimpangnya yaitu mengandung minyak atsiri 2,4\%-3,9\%, juga cinnamal, aldehide, asam motil pcumarik, asam annamat, etil asetat dan pentadekan. Rimpang kencur mengandung sineol, paraumarin, asam anisic, gom, pati $4,14 \%$ dan mineral $13,73 \%$ (Rukmana,1994).

Penelitian Pratiwi (2001) dalam Charunia (2009), menunjukkan bahwa minyak atsiri rimpang temugiring mempunyai daya anti jamur terhadap Candida albican. Minyak atsiri yang digunakan secara langsung dengan dioleskan pada permukaan kulit akan mudah menguap dan daya lekatnya kurang optimal, oleh karena itu perlu dibuat sediaan salep sehingga mudah digunakan.

Salep adalah sediaan setengah padat yang mudah dioleskan dan digunakan sebagai obat luar, bahan aktif akan larut atau terdispersi secara homogen dalam basisi salep yang cocok. Salep terdiri dari basis salep yang merupakan pembawa bersama kombinasi bahan aktif.

Penelitian ini bertujuan untuk membandingkan aktivitas antibakteri berupa salep dengan bahan aktif kunyit, kencur dan temugiring terhadap Bakteri Staphylococcus aureus".

\section{METODE PENELITIAN}

Jenis penelitian yang digunakan adalah Eksperimental dan desain penelitian yang digunakan adalah Static Group Comparasion.

\section{HASIL PENELITIAN}

Penelitian dimulai dengan melakukan ekstraksi serbuk rimpang 
bahan aktif dari kunyit, kencur dan temugiring, sebagai bahan aktif pembuatan salep yang akan diuji. Metode ekstraksi yang digunakan adalah, Proses maserasi menggunakan alkohol $70 \%$ sebagai larutan penyari. Setelah memperoleh ekstrak kental bahan aktif, kemudian dilakukan pembuatan sediaan salep dengan bahan aktif ekstrak kental dari ketiga rimpang di atas.

Uji aktivitas bakteri dilakukan dengan 2 metode, yaitu metode sumuran dan metode difusi yang mengacu pada uji Kirby dan Bauer. Hasil pengamatan dengan metode paper disk seperti tersaji pada tabel 1. berikut.

\section{Tabel 1}

Diamater Zona Hambat Uji Aktivitas

Salep dengan Bahan Aktif Ekstrak

Kunyit, Kencur, dan Temugiring

Terhadap Bakteri Staphylococcus aureus

\begin{tabular}{|c|c|c|c|c|c|c|}
\hline \multirow[t]{2}{*}{ Jenis salep } & \multirow[t]{2}{*}{ Ulangan } & \multicolumn{4}{|c|}{$\begin{array}{c}\text { Diameter zona } \\
\text { bening }(\mathrm{mm})\end{array}$} & \multirow{2}{*}{$\begin{array}{c}\text { Rata- } \\
\text { rata }\end{array}$} \\
\hline & & A & B & $\mathrm{C}$ & D & \\
\hline \multirow{2}{*}{ Kencur } & 1 & 7 & 8 & 7 & 7 & \multirow{2}{*}{7,625} \\
\hline & 2 & 8 & 8 & 9 & 7 & \\
\hline \multirow{2}{*}{ Kunyit } & 1 & 7 & 6 & 6 & 7 & \multirow{2}{*}{6,750} \\
\hline & 2 & 7 & 8 & 7 & 6 & \\
\hline \multirow{2}{*}{ Temugiring } & 1 & 6 & 6 & 6 & 7 & \multirow{2}{*}{6,125} \\
\hline & 2 & 6 & 6 & 6 & 6 & \\
\hline \multirow{2}{*}{ Kontrol } & 1 & 6 & 6 & 6 & 6 & \\
\hline & 2 & 6 & 6 & 6 & 6 & 6,000 \\
\hline
\end{tabular}

Berdasarkan Tabel 1 zona bening dari hasil uji aktivitas bakteri dengan dapat digambarkan bahwa ketiga jenis salep tersebut mempunyai aktivitas menghambat pertumbuhan bakteri yang berbeda. Salep dari bahan aktif kencur mempunyai daya hambat bakteri yang paling tinggi dibandingkan dengan salep dari bahan aktif yang lain.

Uji aktivitas bakteri salep dengan bahan aktif ekstrak kunyit, kencur dan temugiring menggunakan metode sumuran, tidak terlihat adanya zona bening yang menggambarkan daya hambat salep tanpa bahan aktif (kontrol negatif) terhadap Staphylococcus aureus

Salep dengan bahan aktif temugiring, menampakkan gambaran seperti pada kontrol negatif, yang berarti salep dengan bahan aktif ekstrak temugiring ini tidak mempunyai aktivitas menghambat pertumbuhan bakteri Staphylococcus aureus

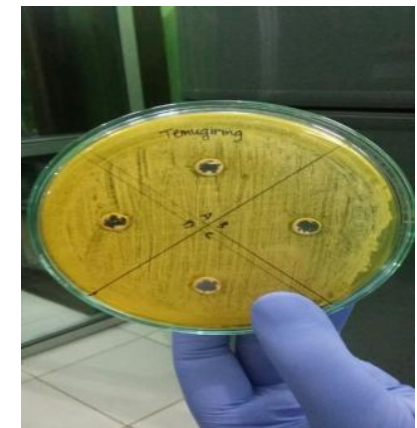

Gambar 1. Aktivitas Salep dengan Bahan Aktif Ekstrak Temugiring dalam Menghambat Pertumbuhan Bakteri Staphylococcus aureus

Aktivitas salep dengan bahan aktif kencur, pengamatan pada sumuran yang dibuat untuk uji aktivitas dapat dilihat adanya zona bening di sekitar sumuran. Hal ini menunjukkan bahwa salep dengan bahan aktif dari ekstrak kencur mempunyai aktivitas dalam menghambat pertumbuhan bakteri Staphylococcus aureus. 


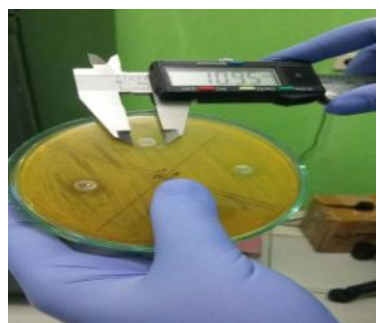

Gambar 2. Aktivitas Salep dengan Bahan Aktif Kencur dalam Menghambat Pertumbuhan Bakteri Staphylococcus aureus

Pengamatan zona bening pada media pertumbuhan, memberikan gambaran bahwa salep dengan bahan aktif kunyit mempunyai aktivitas dalam menghambat pertumbuhan bakteri.

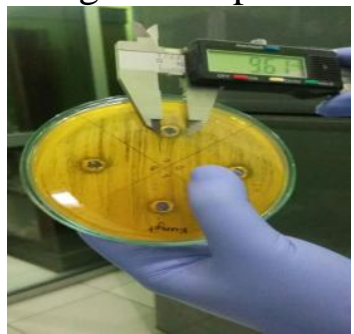

Gambar 3. Aktivitas Salep dengan Bahan Aktif Kunyit Terhadap

Pertumbuhan Bakteri Staphylococcus aureus

Setiap jenis salep dilakukan pengujian ulangan 4 kali dengan zona A, B, C dan D. Rata-rata aktivitas salep dalam menghambat pertumbuhan bakteri seperti tersaji pada tabel 2 . berikut.

Tabel. 2

Diameter Zona Hambat Uji Aktivitas Antibakteri Salep Bahan Aktif Ekstrak Kunyit, Kencurdan Temugiring Terhadap Bakteri Staphylococcusaureus.

\begin{tabular}{llc}
\hline No & Salep & Rata-rata \\
\hline 1. & Kontrol & 6,49 \\
2. & Temugiring & 7,89 \\
3. & Kencur & 13,26 \\
4. & Kunyit & 14,52 \\
\hline
\end{tabular}

Aktivitas salep dengan bahan aktif temugiring, kunyit, dan kencur menunjukkan aktivitas yang berbeda dalam menghambat pertumbuhan bakteri
Staphylococcus aureus. Salep dengan bahan aktif kunyit mepunyai aktivitas menghambat Staphylococcus aureus yang lebih baik, hal ini diketahui dari diameter zona bening di sekitar sumuran yang merupakan hasil aktivitas dari bahan aktif salep dalam menghambat pertumbuhan bakteri.

\section{PEMBAHASAN}

Hasil uji aktivitas menggunakan metode difusi (paper disk) secara visual dengan cara mengamati zona bening pada media pembiakan, menunjukkan bahwa ada perbedaan aktivitas antibakteri dari ketiga jenis salep tersebut. Aktivitas antibakteri tertinggi terjadi pada salep dengan bahan aktif dari ekstrak kencur dengan rata-rata zona penghambatan $7,625 \mathrm{~mm}$, kemudian salep dengan bahan aktif kunyit, rata-rata zona $6,750 \mathrm{~mm}$. Adapun untuk salep dengan bahan aktif temugiring dan salep tanpa bahan aktif (kontrol negatif) rata-rata daya hambatnya masing-masing 6,125 mm. Pada kedua jenis salep tersebut tidak terjadi aktivitas penghambatan pertumbuhan bakteri. Hal ini tidak sesuai dengan penelitian Murniati (2007), bahwa ekstrak etanol temugiring yang diukur metode difusi menunjukkan hasil bahwa ektrak etanol temugiring mempunyai daya hambat terhadap pertumbuhan bakteri Staphylococcus aureus.

Perbedaan konsentrasi atau volume bahan aktif akan mempengaruhi hasil uji aktivitas. Perbedaan hasil ini kemungkinan dapat juga disebabkan asal dari bahan baku sebagai sumber bahan aktif yang digunakan. Analisis statistik menggunakan Anova satu arah, dengan Significance level 5\%, diperoleh $p$ value 0,000 , yang berarti bahwa salep dengan bahan aktif ekstrak kencur, kunyit dan 
temugiring, secara statistik mempunyai aktivitas yang berbeda dalam menghambat pertumbuhan bakteri Staphylococcus aureus.

Uji aktivitas bakteri dengan metode difusi (paper disk) dengan diameter awal $6 \mathrm{~mm}$ menunjukkan bahwa, secara visual ketiga jenis salep dengan bahan aktif kunyit, kencur, dan temugiring, mempunyai aktivitas yang berbeda dalam menghambat pertumbuhan bakteri Staphylococcus aureus. Aktivitas tertinggi pada salep dengan bahan aktif ekstrak kencur dengan rata-rata zona hambat 7,62 $\mathrm{mm}$, salep dengan bahan aktif kunyit rata-rata diameter zona penghambatan $6,75 \mathrm{~mm}$, salep dengan bahan aktif temugiring rata-rata zona beningnya $6,00 \mathrm{~mm}$, sedangkan kontrol negatif rata-rata zona bening $6,00 \mathrm{~mm}$. Hal ini memberikan gambaran bahwa salep dengan bahan aktif temugiring tidak mempunyai aktivitas menghambat bakteri Staphylococcus aureus.

Hasil penelitian ini sesuai dengan hasil penelitian Hartati (2013), bahwa secara in vitro maupun in vivo, kunyit bersifat antimikroba yang dapat membunuh dan menghambat pertumbuhan beberapa jenis jamur, bakteri dan virus. Senyawa kurkumin yang terkandung dalam rimpang kunyit juga toksik terhadap beberapa bakteri seperti Staphylococcus aureus, Micrococcus pyrogenes

Analisis statistik menggunakan Anova satu arah, dengan Significance level $5 \%$, diperoleh $p$ value 0,000 . Hal ini menunjukkan bahwa secara statistik salep dengan bahan aktif kunyit, mempunyai aktivitas yang berbeda dalam menghambat bakteri Staphylococcus aureus.

Hasil uji aktivitas anitbakteri dengan menggunakan metode difusi maupun sumuran, menunjukkan bahwa hasil uji kedua metode tersebut itu saling mendukung, dan tidak saling berlawanan.

Secara deskriptif, dengan melihat luas diameter zona bening sumuran, diameter sumuran awal untuk semua jenis salep sama yaitu $6,5 \mathrm{~mm}$, hasil penelitian mendapatkan bahwa secara berurutan yang mempunyai daya hambat paling baik adalah salep dengan bahan aktif kencur dengan diameter zona bening $(14,52 \mathrm{~mm})$, kemudian kunyit $(13,26 \mathrm{~mm})$ dan terakhir adalah temugiring $(7,89 \mathrm{~mm})$.

Sedangkan kontrol negatif menunjukkan zona bening $(6,49 \mathrm{~mm})$. Diameter zona bening menunjukkan aktivitas dari salep terhadap bakteri Staphylococcus aureus. Pada kontrol negatif diameter menunjukkan $6,49 \mathrm{~mm}$ dari diameter awal $6,50 \mathrm{~mm}$, hal ini berarti bahwa pada kontrol negatif tidak terjadi aktivitas terhadap penghambatan pertumbuhan bakteri sama sekali.

\section{KESIMPULAN DAN SARAN}

1. Ketiga jenis salep mempunyai aktivitas yang berbeda dalam menghambat bakteri Staphylococcus aureus

2. Urutan aktivitas antibakteri terbaik adalah salep dengan bahan aktif ekstrak kencur, kunyit dan temugiring

Saran yang diajukan yaitu Kepada peneliti selanjutnya agar dapat memilih bahan aktif penelitian lebih teliti dan memastikan kandungan zat aktif pada bahan tersebut

\section{DAFTAR RUJUKAN}

Anonim, 2013. Khasiat Kunyit Sebagai Obat Tradisional dan manfaat Lainnya. Warta Penelitian dan pengembangan

Tumbuhan Industri. Vol. 19 (2). 
Charunia, D., 2009. Formulasi Salep Minyak Atsiri Rimpang Temu Giring (Curcuma heyneana Val and v. Zijp) dan Uji Aktivitas Candida albicans in vitro Menggunakan Basis

Polietilenglikol 4000 dan Polietilengglikol 400. Skripsi. Universitas Muhammadiyah Surakarta. Surakarta.

Hartati, Liza Md. S., Azila Abd. A and Mohd Azizi C.Y.(2013). Pengaruh Jenis Pelarut Ekstraksi Biji Mahoni (Swietenia mahagoni Jacq) Terhadap Aktivitas Antioksidan dan Antibakteri, Jurnal Bionature, Volume 14 (1): 11-15.

Murniati, 2007.Antibakteri Rimpang Temu Giring (Curcuma heyneana Val. Zijp) Pengeringan Sinar Matahari Tidak Langsung dan Freeze Drying terhadap Pertumbuhan Staphylococcus aureus Secara In vitro. Skripsi. Universitas Surabaya. Surabaya.

Peoloengan, M., dkk., 2006. Aktivitas Antimikroba dan Fitokimia dari Beberapa Tumbuhan Obat. Seminar Nasional Teknologi Peternakan dan Veteriner. 